Dzieje Najnowsze, Rocznik XLIX - 2017, 1

PL ISSN 0419-8824

MATERIAŁY

\title{
The Collapse of France. Nieznane memorandum brytyjskie dotyczące przyczyn i okoliczności klęski Francji w 1940 r.
}

Dzieje upadku państwa francuskiego latem 1940 r. oraz jego przyczyn doczekały się już w światowej, a także rodzimej historiografii wielu analiz i omówień. Podobnie zreszta jak historia fiaska brytyjsko-francuskiej appeasement policy, która umożliwiła Adolfowi Hitlerowi „pokojowe” wpierw rozmontowanie systemu wersalskiego poprzez przyłączenie Austrii do Rzeszy i likwidację Czechosłowacji, a następnie i tak nie zapobiegła napaści Niemiec na Polskę, a w konsekwencji wybuchowi kolejnego światowego konfliktu ${ }^{1}$. Niemniej

\footnotetext{
${ }^{1}$ W tym miejscu, jedynie ad exemplum rzecz jasna, warto wymienić z literatury kolejno anglosaskiej, francuskiej, niemieckiej i polskiej takie pozycje, jak: A. Adamthwaite, France and the Coming of the Second World War 1936-1939, London 1977; A.M. Cienciała, Poland and the Western Powers 1938-1939, London-Toronto 1968; M. Cowling, The Impact of Hitler. British Politics and British Policy 1933-1940, Cambridge 1975; D. Faber, Munich 1938. Appeasement and the World War II, New York-London 2008; T.C. Imlay, Facing the Second World War. Strategy, Politics and Economics in Britain and France 1938-1940, Oxford 2003; C. Leibowitz, The Chamberlain-Hitler Deal, Edmonton 1993; C.A. MacDonald, The United States. Britain and Appeasement 1936-1939, New York 1981; F. McDonough, Neville Chamberlain, Appeasement and the British Road to War, Manchester 1998; K. Middlemas, Diplomacy of Illusion. The British Government and Germany 1937-1939, London 1972; W. Murray, The Change in the European Balance of Power 1938-1939. The Path to Ruin, Princeton 1984; P. Neville, Hitler and Appeasement. The British Attempt to Prevent the Second World War, New York 2006; R.A.C. Parker, Chamberlain and Appeasement. British Policy and the Coming of the Second World War, London 1993; A.J. Prażmowska, Eastern Europe and the Origins of the Second World War, New York 2000; H. Ragsdale, The Soviets, the Munich Crisis and the Coming of the World War II, Cambridge 2004; W. Rock, Appeasement on Trial. British Foreign Policy and its Critics 1938-1939, London 1966; A.L. Rowse, Appeasement. A Study in Political Decline 1933-1939, New York 1961; W.L. Shirer, The Collapse of the Third republic. An inquiry into the Fall of France in 1940, New York 1994; The Fascist Challenge and the Politics of Appeasement, ed. W.J. Mommsen, L. Kettenacker, London 1983; The Munich Crisis 1938. Prelude to World War II,
} 
każdy kolejny przyczynek, tym bardziej źródłowy, który w pełniejszy sposób tłumaczy francuska politykę doby Monachium i tzw. aktywnej fazy polityki zaspokajania oraz ostatnich miesięcy przed upokarzajacym rozejmem z Compiègne, a także zaraz po nim, jest ze wszech miar cenny i winien według nas jak najszybciej trafić do obiegu naukowego.

Właśnie do grupy tego rodzaju dokumentów należy, jak uważamy, opracowany przez nas poniżej materiał. Sporządzony w języku angielskim i opatrzony znamiennym tytułem - The Collapse of France, znalazł się on w kolekcji ambasadora Michała Sokolnickiego, przechowywanej w archiwum nowojorskiego Instytutu Józefa Piłsudskiego ${ }^{2}$. Na dokumencie widnieje adnotacja, iż przygotowany on został w formie memorandum przez ambasadora Vichy w Ankarze w latach 1942-1944, Gastona Bergery'ego, a następnie poufnie przesłany Laurence Steinhardtowi - amerykańskiemu ambasadorowi w Turcji. Czy jednak w istocie francuski dyplomata jest jego faktycznym autorem? I co dokument ten robi w papierach Sokolnickiego? To niezmiernie ważkie pytania, zważywszy nie tylko na samą treść dokumentu, ale również ze względu na próbę wskazania, po co to źródło w ogóle powstało. Postaramy się na nie odpowiedzieć.

ed. I. Lukes, E. Goldstein, London-Portland 1999; D.C. Watt, How War Came. The Immediate Origins of the Second World War 1938-1939, London 1989; J.P. Azéma, De Munich à la Libération, Paris 1992; R. Boyer de Sainte-Suzanne, Une politique étrangère. Le Quai d'Orsay et Saint-John Perse à l'épreuve d'un regard. Journal novembre 1938 - juin 1940, par H. et P. Levillain, Paris 2002; R. Coulondre, De Staline à Hitler. Souvenirs de deux ambassades 1936-1939, Paris 1950; J.B. Duroselle, L'abîme 1939-1945, Paris 1982; idem, La décadence (1932-1939), Paris 1979; idem, Politique extérieure de la France. La décadence (1932-1939), Paris 1980; R. Girault, R. Frank, La puissance en Europe 1938-1940, Paris 1983; M. Hauner, Edvard Beneš et Munich, w: La Tchécoslovaquie - sismographe de l'Europe au XXe siècle, éd. A. Marès, Paris 2009; Y. Lacaze, La France et Munich. Étude d'un processus decisionnel en matière de relations internationales, Paris 1979; idem, L'opinion publique française et la crise de Munich, Berne 1991; P. Miquel, Le piège de Munich, Paris 1998; É. Réau, Édouard Daladier 1884-1970, Paris 1993; H. Bartel, Frankreich und die Sowjetunion 1938-1940. Ein Beitrag zur französischen Ostpolitik zwischen dem Münchner Abkommen und dem Ende der Dritten Republik, Stuttgart 1986; H.G. Bellstedt, „Apaisement" oder Krieg. Frankreichs Außenminister Georges Bonnet und die deutsch-französische Erklärung vom 6. Dezember 1938, Bonn 1993; B. Celovški, Das Münchener Abkommen 1938, Stuttgart 1958; A. Hillgruber, Der Zweite Weltkrieg 1939-1945. Kriegsziele und Strategie der großen Mächte, Freiburg 1982; Mythos München. Le Mythe de Munich. The Myth of Munich, ed. F. Taubert, München 2002; H. Batowski, Kryzys dyplomatyczny w Europie. Jesień 1938 - wiosna 1939, Warszawa 1962; idem, Rok 1938 - dwie agresje hitlerowskie, Poznań 1985; idem, Zdrada monachijska. Sprawa Czechostowacji i dyplomacja europejska w roku 1938, Poznań 1973; M. Kornat, Polityka zagraniczna Polski 1938-1939. Cztery decyzje Józefa Becka, Gdańsk 2012; P.M. Majewski, Nierozegrana kampania. Możliwości ochronne Czechostowacji jesienia 1938 roku, Warszawa 2004; M. Zgórniak, Europa w przededniu wojny. Sytuacja militarna w latach 1938-1939, Kraków 1993.

2 Archiwum Instytutu Józefa Piłsudskiego w Nowym Jorku (dalej: AIJP/NJ), Archiwum ambasadora Michała Sokolnickiego (dalej: AMS), kol. 91/103, The Collapse of France, k. 298-313. 
Zacznijmy jednak od pochylenia się nad samą treścią memoriału, którego krótki przegląd winien ułatwić nam powyższe zadanie. Na początek należy zaznaczyć, że nawet bez precyzyjnego określenia autora memorandum, jest ono niebywale ciekawe i warte według nas lektury. Podzielony na części, z wyraźnie wyszczególnionymi śródtytułami, dokument dotyka problematyki zagadnień związanych z polityką zagraniczna, jak i wewnętrzną państwa francuskiego na tle rozgrywających się wówczas wydarzeń w Europie przed wybuchem II wojny światowej - szczególnie w czasie kryzysu lat 1938-1939 oraz już w trakcie pierwszych miesięcy konfliktu, po których nastapił atak Niemiec na Francję i jej upadek. Scharakteryzowano sytuację III Republiki i jej położenie w dobie gabinetów tworzonych przez przedstawicieli Frontu Ludowego, począwszy od zwycięskich, przez koalicję wyborów z maja 1936 r. Okres ten został przedstawiony w ciemnych barwach i oceniony wielce negatywnie, głównie ze względu na prowadzoną przez ówczesne rządy politykę społeczną (socjalna), ale również z powodu ich ogólnych poczynań, które nie najlepiej wpływały na międzynarodową rolę i znaczenie Paryża. W memoriale zwrócono uwagę na skutki Wielkiej Wojny i ich wpływ na późniejszą politykę Francji oraz głos jej opinii publicznej. Przez ten pryzmat postrzegano wśród francuskich decydentów, również wojskowych, a także w społeczeństwie, zobowiązania III Republiki wobec sojuszników z Europy Środkowo-Wschodniej - Czechosłowacji i Polski. Naród francuski i jego kierownicy w żadnym razie nie myśleli poważnie o tych układach i ewentualnej pomocy dla wspomnianych państw, czego najlepszym przykładem był opublikowany $4 \mathrm{~V} 1939 \mathrm{r}$. artykuł pt. Mourir pour Dantzig, a następnie jego entuzjastyczne przyjęcie ${ }^{3}$. Dużą rolę za to przywiązywano do relacji z Wielką Brytanią. Zaangażowanie Zjednoczonego Królestwa w kryzys monachijski i obrana przez Londyn postawa (appeasement policy) wynikały jednakże nie tylko z zobowiązań wobec partnera zza kanału La Manche, ale również z realnego oglądu sytuacji i ze znajomości złego stanu przygotowań armii francuskiej do wojny. Według Downing Street Francja potrzebowała jeszcze czasu, aby odzyskać swoją wartość bojową. Interesujące w tym względzie były odnotowane w memorandum opinie na temat dalszego przebiegu wypadków i sugerowanych już wówczas zmian w powszechnym obowiązku służby wojskowej zarówno we Francji, jak i Wielkiej Brytanii, a także ich zamorskich posiadłościach, czynione przez niemiecką generalicję w 1939 r. Dodajmy, że w tym kontekście niemniej ważkie są zamieszczone w memoriale poglądy na temat występujących nad Sekwana nastrojów pacyfistycznych w przededniu wybuchu wojny, w pierwszych dniach jej trwania (tzw. dziwna wojna) oraz już po zakończeniu kampanii polskiej. Z dokumentu dowiemy się także o przyczynach upadku gabinetu Édouarda Daladiera i w konsekwencji zastapieniu go przez Paula Reynauda. Przedstawiony został dalszy przebieg wypadków - niemiecki atak na Danię i Norwegię

3 „L'EEuvre”, 4 V 1939. 
oraz Belgię, Holandię, Luksemburg i Francję. W związku z tym swój opis znalazła III Republika pod rządami Philippe’a Pétaina oraz Pierre’a Lavala. W tamtym czasie, co w dokumencie uwypuklono, polityka marszałka Pétaina była akceptowana przez większość społeczeństwa francuskiego. Memoriał przynosi również rozważania nad dalszymi relacjami angielsko-francuskimi oraz nad polityczną droga, jaką Francja może obrać w najbliższej przyszłości. W memorandum śledzimy zatem nie tylko konkretne posunięcia francuskich decydentów politycznych i wojskowych w tym jakże przełomowym dla Europy i świata czasie, ale też ich rozważania, przemyślenia, wątpliwości i obawy wynikające z dynamicznej sytuacji rozgrywającej się na kontynencie, która mogłaby przynieść - patrząc przez pryzmat skrajnych wariantów - wybuch wojny bądź spektakularna utratę prestiżu przez Francję oraz - w obliczu upadku - jej dalsze losy.

Wydźwięk dokumentu, jak Czytelnik niżej zobaczy, a o czym już wspomnieliśmy, jest wyraźnie antylewicowy i zarazem wielce krytyczny wobec rządów Frontu Ludowego ostatniego okresu sprzed wybuchu II wojny światowej i napaści Niemiec na Francję. Narracja idzie po takiej linii, iż łatwo może się wydawać, że pióro, które ją kreśliło, dzierżył polityk francuskiej prawicy, może reprezentant Vichy. A nim przecież był Bergery - i tu wszystko by się zgadzało. Tym więcej, iż w tym momencie z pomoca przychodzi nam ambasador Sokolnicki, który na marginesie jednego z listów do Wacława Jędrzejewicza, pisanego w marcu 1947 r., napomknął, że załącza w nim jako „ciekawostkę do archiwów Instytutu [Józefa Piłsudskiego w Nowym Jorku] - odpis memoriału przekazanego w 1944 Rooseveltowi przez Ambasadora Vichy w Ankarze p. Bergery"4. W innym miejscu Sokolnicki dopowiadał, że memoriał Bergery'ego wręcz krążył po tureckiej stolicy i „przepowiadał z rzadka, prorocza przenikliwością niebezpieczeństwo zaborczego bolszewizmu, zalegające jak ciemna chmura nad Europa" ". Zagadka wydaje się rozwiązana. Francuski ambasador sporządził memorandum, które adresowane do przywódcy Stanów Zjednoczonych trafiło wpierw do rąk Steinhardta - naturalnego pośrednika. Rok 1944 jako czas powstania dokumentu jest dla nas jak najbardziej przekonujaccy. To czas rozrachunku Bergery'ego z kolaboracyjnym reżymem i moment opuszczenia przezeń Turcji. Ponadto nie ma powodów, by pedantyczny wręcz $\mathrm{w}$ archiwizowaniu wiadomości Sokolnicki miał się pomylić w datacji, i to w tak krótkim czasie od momentu opisywanych wydarzeń. Nietrudno również wytłumaczyć, skąd odpis owego memoriału znalazł się w prywatnych zbiorach polskiego ambasadora. Jak wiadomo, Michał Sokolnicki - od 1936 r. ambasador Rzeczypospolitej w ojczyźnie Atatürka, a od przełomu 1941/1942 dziekan tamtejszego korpusu zagranicznego - posiadał znakomite stosunki

\footnotetext{
${ }^{4}$ AIJP/NJ, AMS, kol. 91/101, List Michała Sokolnickiego do Wacława Jędrzejewicza z 29 III $1947 \mathrm{r}$.

${ }_{5}^{5}$ M. Sokolnicki, Von Papen i nieudane próby pokoju, „Wiadomości” (Londyn) 1952, nr 347, s. 3.
} 
wśród tureckich decydentów, jak i akredytowanych w Ankarze dyplomatów ${ }^{6}$. Dokument więc mógł zostać po prostu poufnie przekazany Sokolnickiemu przez Steinhardta. To, że bardzo bliskie kontakty między nimi istniały, jest pewne ${ }^{7}$. Przykładowo z końcem maja 1944 r. amerykański dyplomata dziękował Sokolnickiemu za przygotowanie i przesłanie mu raportu dotyczacego losów polskich Żydów podczas okupacji niemieckiej. ${ }^{8}$. Ten kilkustronicowy dokument, swoją droga, również się zachował ${ }^{9}$. Znajduje się on w tej samej teczce, co opracowywany przez nas materiał, co może świadczyć o tym, iż ambasador Stanów Zjednoczonych przekazując memorandum polskiemu dyplomacie, w ten sposób mu się odwdzięczał. A być może jest to po prostu dowód na zaufanie i wzajemną współpracę obu panów.

Problem jednak w tym, że z treści dokumentu wynika, iż za jego autorstwo moga być odpowiedzialni... Brytyjczycy. Jak inaczej bowiem tłumaczyć passus traktujący o potencjalnym wybuchu wojny jesienia 1938, gdzie w tekście jasno stoi, że "We had no obligation to Czechoslovakia outside the League, to which body no appeal was ever made. Our only commitment was to France and it was only in the case of that country becoming involved in war, or by a general decision of the League, that we should have come into the business". Albo weźmy kolejny przykład odnoszacy się do przełomowych dni sporu niemiecko-czechosłowackiego i reakcji nań Francji: "During the critical days of that crisis we sent one of our observers to Paris in order to watch the trend of opinion. He arrived at a time when war seemed inevitable, and when the French Government was declaring daily that it would carry out its obligations to the letter". W innym miejscu znalazło się następujące zdanie: "It was not for us at that to assume that France had no longer any military value whatsoever. We were obliged to assume that although she had gone through difficulties, her recovery was only a matter of time, and that if she could be tided over a bad moment she would recover her position as a great power. It was, therefore, of vital importance that she should save her prestige and honour at any reasonable cost. It was this as much as anything else which led Great-Britain to insist upon a proper diplomatic settlement of the dispute". I jeden z najbardziej znamiennych cytatów: "During a couple of days stay in the French capital we had a number of conversations. We had

\footnotetext{
${ }^{6}$ Zob. K. Kloc, Michat Sokolnicki. Portret ambasadora Rzeczypospolitej Polskiej w Turcji (1936-1945), „Niepodległość” 2014, t. LXIII, s. 247-262; AIJP/NJ, AMS, kol. 91/98, List Michała Sokolnickiego do Władysława Pobóg-Malinowskiego z 12 I 1947 r.

${ }^{7}$ Bliskie i serdeczne kontakty istniały pomiędzy oboma ambasadorami już od pierwszej wizyty Amerykanina u Sokolnickiego 11 III 1942 r. M. Sokolnicki, Dziennik Ankarski 1939-1943, Londyn 1965, s. 329-331.

8 Archiwum Akt Nowych w Warszawie, Ambasada RP w Ankarze, sygn. 70, List Laurence'a Steinhardta do ambasadora Michała Sokolnickiego z 29 V 1944 r., k. 32.

9 AIJP/NJ, AMS, kol. 91/103, Notice sur le Sort des Juifs en Pologne, k. 314-316. Dokument powstał $25 \mathrm{~V} 1944 \mathrm{r}$.
} 
one and a half hours with M[ister] Leger ${ }^{10}$, permanent head of the French Foreign Office... We found that M[ister] Leger, when cross examined, related the whole of French Foreign Policy to the question of what contribution of a military character Great-Britain might be prepared to make. This seems to be the end of everybody's observations, and we left Paris with the feeling that if France is threatened with a serious international situation, she will make her policy conditional upon our ability to land at any given time a very substantial expeditionary force, and that if we cannot promise this, France may capitulate, throwing the blame upon us..."

W związku z tym przypuśćmy, że być może Bergery, wchodząc w Ankarze w konszachty z Anglikami, z ich niewątpliwej inspiracji oraz przy jawnym współudziale sporządził poniższy dokument, którym definitywnie zrywał w oczach aliantów z Vichy i dawał im jednocześnie pewne wskazówki, co łatwo w dokumencie wyczytać, dotyczące potencjalnej wizji polityki francuskiej w bliskim powojennym okresie. Bergery nie był poważną figura na firmamencie politycznym Francji, a jego nominacja na ankarską placówkę wynikała z tego, że jak twierdził jego poprzednik w tureckiej stolicy Jean Helleu - „po prostu chciano się go pozbyć” z Moskwy, gdzie dotychczas przebywał, reprezentując interesy Vichy ${ }^{11}$. Po trosze był on koniunkturalista, który jednako największe zagrożenie widział w bolszewizmie. Jego wolta stałaby się zatem prawdopodobna. Poniekąd zgadzać by się to mogło z obserwacjami Michała Sokolnickiego, który w listopadzie 1943 r. raportował do Londynu, że „tut[ejsza] ambasada francuska (Vichy) jest w praktyce w stanie likwidacji. Ostatnio na stronę Algieru przeszło 5 urzędników. Żegnając się z nimi ambasador Bergery oświadczył, że nie dziwi się ich decyzji. Attachés wojskowi choć pozostali w ambasadzie służą jednak sprawie Francji Walczącej. $\mathrm{B}$ [ergery] podkreślał ostatnio na zewnątrz swoje neutralne stanowisko" ${ }^{12}$. Inna możliwość jest taka, że memorandum to w całości zostało przygotowane przez Brytyjczyków i jakimś sposobem trafiło do rąk francuskiego dyplomaty, a ten dostarczył je następnie Amerykanom. Pamiętajmy, że Sokolnicki nie wskazał ambasadora Vichy jako konkretnego autora dokumentu, a jedynie wspomniał, że ten memoriał przekazał. Istotna to według nas różnica. Ponadto watpimy, by pozostawiona na memorandum adnotacja, mówiąca o Bergerym jako twórcy tekstu, została pisana ręką Sokolnickiego. Przywołany bowiem w niej jest ze znakiem zapytania czas powstania (bądź przekazania) dokumentu - 1943/1944, podczas gdy ambasador we wspomnianym już liście do Jędrzejewicza wskazywał rok 1944. Niestety nie potrafimy, w obliczu braku

\footnotetext{
${ }^{10}$ Marie-René-Alexis Léger (pseud. Saint-John Perse; 1887-1975), francuski dyplomata i poeta, w latach 1933-1940 sekretarz generalny francuskiego MSZ, laureat literackiej Nagrody Nobla za rok 1960.

${ }^{11}$ M. Sokolnicki, op. cit., s. 380.

12 AIJP/NJ, AMS, kol. 91/21, Szyfrogram ambasadora Michała Sokolnickiego do Londynu nr 234 z dn. 11 XI [1943] - zwykły.
} 
dokładniejszego przekazu źródłowego, konkretniej wyjaśnić tej sprawy. Uważamy wszelako, patrzac jedynie przez pryzmat samej treści memoriału, która stanowi dla nas najważniejszą poszlakę, i dokonując jej źródłowej krytyki, iż samodzielne autorstwo Brytyjczyków jest o wiele bardziej prawdopodobne i my je przyjmujemy. Stąd też w tytule naszego opracowania dokument wprost nazywamy „memorandum brytyjskim”.

Ze względów technicznych w dokumencie poprawiliśmy błędy gramatyczne, ortograficzne i stylistyczne. Wszystkie dopisane odręcznie wyrazy oraz skróty wzięliśmy w nawias kwadratowy lub wyjaśniliśmy w przypisie. Występujące w tekście liczne kropki ograniczyliśmy do wielokropków “...”. Przyjęliśmy też występujący w języku angielskim tzw. górny cudzysłów. Staraliśmy się również, w miarę możliwości, tłumaczyć pojawiające się w dokumencie najważniejsze problematy oraz podać podstawowe informacje o występujących w nim osobach. W przypadku tych ostatnich było to, bez uniknięcia potencjalnego błędu, niekiedy niemożliwe, stąd też w takim wypadku wstawialiśmy zdanie o tym, że „nazwisko ministra nie do ustalenia” lub „nie sposób ustalić, o którym francuskim premierze mowa”.

Opracowali, wstępem i przypisami opatrzyli oraz do druku podali Krzysztof Kania Toruń Krzysztof Kloc Kraków 


\author{
$* * *$ \\ Memorandum p[ana] Bergery ${ }^{14}$, Ambasadora ${\frac{\text { Secret }^{13}}{\text { Francji }}}^{13}$ \\ przestane poufnie Ambasadorowi USA w Ankarze ${ }^{15}$ \\ $1943 / 44$ (?) \\ nie do publikacji \\ chyba za zgoda Dep[ar]t[ment] of State
}

\title{
THE COLLAPSE OF FRANCE
}

The Follies of M[ister] Blum.

Space will not allow us to review French Politics since the armistice of 1918, nor indeed to give even the broadest sketch of all political events since the last general election. Those of the crisis itself are complex enough, and will tax our space to the utmost. It is sufficient to say that when as a result of the last election to the Front Populaire Government came to power ${ }^{16}$, a series of disasters commenced which are largely responsible for, and have ended in, the armistice of June $1940^{17}$. The election brought a considerable number of Communist Deputies and extreme Leftists to the Chamber ${ }^{18}$, whose mischievous influence, and persistent intrigue, played a deadly part. At a time when the highest possible industrial output was necessary for the very life of France, the country was plunged into a series of deplorable disputes and strikes from which she never recovered.

${ }^{13}$ Dopisane odręcznie czerwonym ołówkiem.

${ }^{14}$ Gaston Bergery (1892-1974), francuski polityk i dyplomata, w czasie II wojny światowej związany z kolaboracyjnym rządem Vichy. Ambasador w Moskwie (1941) oraz w Ankarze (1942-1944).

15 Laurence Steinhardt (1892-1950), amerykański działacz syjonistyczny i dyplomata, ambasador Stanów Zjednoczonych w Szwecji, Peru, ZSRS, Turcji (1942-1945), Czechosłowacji oraz Kanadzie.

${ }^{16}$ Mowa o francuskim Froncie Ludowym - zawiązanej w 1935 r. koalicji socjalistów z Section française de l'Internationale ouvrière (SFIO), z Parti républicain, radical et radical-socialiste oraz komunistów, która to w maju 1936 r. wygrała wybory parlamentarne i objęła władzę we Francji.

17 Układ o zawieszeniu broni pomiędzy Francją a Niemcami, który w życie wszedł 25 VI 1940 r., podpisano w Compiègne 22 VI 1940 r.

${ }_{18}$ W liczącej 608 miejsc Izbie Deputowanych Front Ludowy zdobył 386 mandatów (komuniści - 72, SFIO - 147, przedstawiciele Partii Radykalno-Socjalistycznej - 167). Na czele rządu stanął Léon Blum. 
The breakdown of the Front Populaire.

Having created black chaos in France, M[ister] Blum's ${ }^{19}$ Government pursued a reckless foreign policy involving France in bitter enmities for which she was to pay dearly. Eventually, the Front Populaire broke down and in due course $\mathrm{M}$ [ister] Daladier ${ }^{20}$ formed a Government with a mandate to put a sorely perplexed country into some sort of order ${ }^{21}$. Unfortunately, events abroad had moved no less swiftly than those at home, and M[ister] Daladier was soon plunged into all the complexities of a European crisis of the first magnitude. It threatened to involve the most serious treaty obligations and to bring about a conflict between France at her lowest ebb, and Germany in the flood tide of her strength.

French commitments in C[entral] Europe.

Throughout all the vicissitudes of domestic politics a small group of intellectuals and diplomatists had steadily maintained the foreign commitments of France, irrespective of the military strength of the country. When the Czechoslovak crisis burst upon Europe, France was under the heaviest obligations from the first moment ${ }^{22}$. Public opinion, still war weary from the struggle of 1914-1918, disillusioned by the reckless irresponsibility of post-war politicians, and revolted by the utter disunity of the country, was totally unprepared to plunge into a great war for a treaty the existence of which it had tried to forget. Indeed, in the public mind, it had really become little more than an archive of the Quai d'Orsay. It was secretly smiled at, even by many members of the Services, for the General Staff had obviously made preparations for nothing more than the defence of the French frontier, whereas the treaty obligations demanded a willingness and preparedness for the offensive.

Great Britain's ignorance of the French mind.

The fact that the French public had not the slightest intention of going to war over Czechoslovakia was, unhappily, little known in London, and the British Government naturally assumed that when the crisis arose, France, under the obligation of assisting her ally would be very largely dependent upon us, and it was for that reason alone that we ever became involved in the Czech crisis at all.

\footnotetext{
${ }^{19}$ Léon Blum (1872-1950), francuski polityk związany z SFIO, z ramienia Frontu Ludowego dwukrotny premier Francji (VI 1936 - VI 1937; III-IV 1938). Podczas II wojny światowej przebywał w niemieckim obozie koncentracyjnym w Buchenwaldzie. W latach 1946-1947 jako przewodniczący Rządu Tymczasowego stał na czele państwa francuskiego.

20 Édouard Daladier (1884-1970), francuski polityk, szef Partii Radykalno-Socjalistycznej, wielokrotny minister oraz premier Francji (I-X 1933; I-II 1934; IV 1938 - III 1940). Od 1943 r. więziony przez Niemców w obozach w Dachau i Buchenwaldzie.

${ }^{21}$ Gabinet Édouarda Daladiera powstał 10 IV 1938 r.

${ }^{22}$ Mowa o francusko-czechosłowackim traktacie przymierza i przyjaźni podpisanym 25 I $1924 \mathrm{r}$.
} 
The reasons for Munich.

The whole world believes that M[ister] Chamberlain ${ }^{23}$ was driven to Munich by the unpreparedness of Britain ${ }^{24}$. Although this was an important factor it was not the only decisive one. We had no obligation to Czechoslovakia outside the League, to which body no appeal was ever made. Our only commitment was to France and it was only in the case of that country becoming involved in war, or by a general decision of the League, that we should have come into the business ${ }^{25}$. It was only in the very middle of the crisis that it became apparent that France had not the slightest intention of carrying out her obligations, and it was at this moment that the appalling dangers of our position became plain.

The Issue before Britain.

If, after all the solemn declarations which France had made, and which we had backed, Germany had marched into Czechoslovakia without the slightest pretence of negotiation and then no nation had moved a finger to check the aggression, the Entente ${ }^{26}$ would have become the laughing-stock of the world and its influence would have been undermined for a decade - and a most important one. It was not for us at that to assume that France had no longer any military value whatsoever. We were obliged to assume that although she had gone through difficulties, her recovery was only a matter of time, and that if she could be tided over a bad moment she would recover her position as a great power. It was, therefore, of vital importance that she should save her prestige and honour at any reasonable cost. It was this as much as anything else which led Great-Britain to insist upon a proper diplomatic settlement of the dispute.

\section{An historic Misconception.}

It was and still is widely believed that the Munich settlement was pressed upon a reluctant France by a Great Britain deadly afraid of war. Although Britain was very reluctant to go to war, and our preparations were incomplete,

${ }^{23}$ Arthur Neville Chamberlain (1869-1940), brytyjski polityk, członek Partii Konserwatywnej, premier rządu Zjednoczonego Królestwa (V 1937 - IX 1939; IX 1939 - V 1940), propagator polityki appeasementu.

${ }^{24}$ Konferencja monachijska, z udziałem Chamberlaina, Daladiera, Hitlera i Mussoliniego, odbyła się 29-30 IX 1938 r. W tym samym miesiącu brytyjski premier dwukrotnie przybywał do Niemiec, aby spotkać się z Adolfem Hitlerem - 15 września w Berchtesgaden oraz 23-24 września w Bad Godesbergu.

${ }^{25}$ Od 14 X 1933 r., po formalnym wystapieniu, Niemcy nie należały do Ligi Narodów. Niemniej zważywszy na to, iż pakt Ligi Narodów nie stawiał wojny poza nawiasem prawa międzynarodowego i poza konkretnymi przypadkami (zob. art. 12 § 1, 2; art. $13 \S 4$; art. 15 § 6) wojna była legalna, to dopuszczano również wojnę obronna, a także wojnę jako sposób rozwiązywania sporów pomiędzy państwami niebędącymi członkami Ligi Narodów oraz między tymi państwami a członkami Ligi.

${ }^{26}$ Popularna nazwa, nawiąująca do okresu Wielkiej Wojny, porozumienia francusko-brytyjskiego. 
the primary object was to save France form the most appalling humiliation, and to escape fighting Germany quite alone over an issue which did not involve our Treaty obligations.

Some interesting reports recalled from 1938.

During the critical days of that crisis we sent one of our observers to Paris in order to watch the trend of opinion. He arrived at a time when war seemed inevitable, and when the French Government was declaring daily that it would carry out its obligations to the letter. Returning on $14^{\text {th }}$ September, he sent in a confidential report, from which the following extract is taken:

"... I returned early this morning from Paris and have somewhat hurriedly drafted a short report of various conversations which I had in the French capital commencing on Sunday morning last, and ending about 4,20 p.m. on Tuesday, $13^{\text {th }}$ September. I regard it as of the utmost importance for London to be fully acquainted with the view held by certain Frenchmen. At the present moment speed seems so important that I must be excused if this memorandum seems lacking in detail and hastily drafted. On Sunday last I had a very long conversation by telephone with... (a famous former Prime Minister of France $)^{27}$ who expressed certain very striking views to me... He seemed to think that the solution proposed in the famous "Times" article is an admirable one ${ }^{28}$, and in any event he regarded the Czech situation as far too confused a one for any definite French decision. Moreover, he informed me he found a considerable amount of hostility in this constituency amongst the peasantry - too much to risk a war for Czechoslovakia, or indeed anything excepting in the defence of France...

I had lengthy conversations with... (a former Minister ${ }^{29}$. He told me that he had seen a number of his colleagues who had arrived in Paris from the country, and they were opposed to intervention. He argued it would be a long and harassing war, and the responsibility of actually commencing hostilities in the West of Europe was too great for France. Their air force was in a deplorable condition... He doubted if the French would march; in fact, he was quite sure they would not. He had had a conversation with... (another former Prime Minister $)^{30}$ which he fully reported to me, and I gathered that while very reserved, is probably of much the same view... Before I set out my general conclusion I must record the fact that I had an interview with the Editor of... ${ }^{31}$

${ }^{27}$ Nie sposób ustalić, o którym francuskim premierze mowa.

${ }^{28}$ Chodzi o głośny artykuł z „The Times”, 7 IX 1938 r., s. 13, w którym po raz pierwszy otwarcie zasugerowano możliwość zrzeczenia się przez Czechosłowację części jej terytorium na rzecz Niemiec. Tekst ten, jako że „The Times” uważany był za nieformalny organ brytyjskiego MSZ, odbił się szerokim echem zarówno na europejskich salonach dyplomatycznych, jak i w prasie.

${ }^{29}$ Nazwisko ministra nie do ustalenia.

${ }^{30}$ Podobnie jak wcześniej, nie wiemy, o którego premiera chodzi.

${ }^{31}$ Nazwisko redaktora nie do ustalenia. 
who expressed the same views in hesitating but unmistakable terms. He assured me that France could not possibly afford at this time to lose any more for her peasant population - that they could only possibly risk this if France was actually attacked, and he stressed the deplorable condition of the air force... ${ }^{32}$ I had many other conversations and I was forced to the same conclusion... I cannot stress it with too great urgency, the importance of a further examination of French public opinion...

I formed the impression that the apparent unanimity of the press may be false and that underneath this, the political situation is unhealthy and divided... Important forces in France feel that they would be fighting for a lost cause which has little to commend it... I must stress French opinion, as I found it, may move more and more towards non-intervention...

Three main considerations arise:

1/ That if these views which came to my knowledge are known in Berlin, it is hardly surprising that Germany is pursuing a reckless policy, especially if our decision is dependent upon French action...

2/ That if the French Government forces the issue in such a way that all patriotic Frenchmen, however reluctant, are obliged to agree to intervention, the subsequent war will be fought on a shaky political foundation, which after some months of hostilities, might have the gravest possible consequences.

3/ That if Germany succeeds in further confusing the issue, the delay which will take place between the outbreak of hostilities in the East, and a decision as to action in the West, will be ample for an appalling political tangle to come about in Paris..."

A critical Sunday.

Opinion was to move rapidly, and always towards a determined pacifism. On Sunday $25^{\text {th }}$ September ${ }^{33}$, a famous French publicist telephone a report to us form Paris ${ }^{34}$, from which the following points were taken:

"He informs me that at the cabinet meeting now taking place in Paris there are serious deference's again. Even if the cabinet becomes agreed, the opposition in parliament to any action likely to lead to war in the West at this time must be serious...

Influential quarters are of the opinion that a French declaration of war now is out of the question, and would be fighting in Germany's time and not in that of the French. He stresses that the French are not ready for a war

${ }^{32}$ Pomimo że lotnictwo Francji w przededniu wojny liczyło ok. 5 tys. samolotów, w tym jedną czwartą stanowiły jednostki bojowe, były to w przeważającej większości samoloty starej generacji.

${ }_{33}$ Dzień po tym, jak Hitler przedstawił w bezpośredniej rozmowie z Chamberlainem nowe niemieckie żądania dotyczące cesji terytorium czeskiego, które zamieszkiwała nie tylko ludność niemiecka, ale również czeska. Brytyjski premier odrzucił te żądania, w związku z czym porozumienie, i co za tym idzie zażegnanie potencjalnego konfliktu, stanęło pod znakiem zapytania.

${ }^{34}$ Nazwisko dziennikarza nie do ustalenia. 
and cannot face it... He will let me know at the end of the French cabinet meeting what decisions there are, if any... He stresses again and again that powerful sections of French opinion are quite united in their determination to oppose any proposals of M[ister] Daladier which might involve the French... One lesson at least stands out and that is that the French are in a very unreliable mood... I hope the Germans are not aware of this, but I am quite sure their sources of information are excellent and that is half our trouble".

Later on that Sunday a further report came by telephone from Paris. It was based upon a conversation with a French statesman, and following is the salient extract:

"... He maintains his view solidly that for France to enter into hostilities now would be nothing short of a disaster. He wants a few months in which to prepare and would like to see the Central European situation rip for the moment. He tells me France can in no circumstances undertake an offensive action, even a defensive one would be hard enough work. Moreover, in view of public sentiment, any initial military reverse would culminate in a civil rebellion. He thinks such a reverse is very possible. He told me he felt that a decision to march now would be one of the greatest mistakes in the history of his country... He would oppose any declaration of war in parliament with all the resources he commands. He was in favour of having his view conveyed to the highest quarters in Britain... I must say greatly impressed by his urgent pleading for caution. He stressed to me the unpreparedness to France in air raid precautions and he went over every point in a lengthy conversation, stressing and restressing his anxiety. He frankly foresees defeat and revolution. He sees France desperately weak in the air and her industry disorganized. He was clearly at his wits and in his sincere and urgent anxiety. I cannot overemphasize the urgency of his plea. He has warned me repeatedly in recent weeks, but now his warning is on very grave terms indeed".

Forces in Favour of peace in 1938.

Powerful forces were at work. Amongst the politicians opposed to intervention on were $\mathrm{M}\left[\right.$ isters] Flandin ${ }^{35}$, Laval ${ }^{36}$, Marcel Déat ${ }^{37}$, Bonnet ${ }^{38}$,

${ }_{35}$ Pierre-Étienne Flandin (1889-1958), francuski polityk, przywódca konserwatywnego Sojuszu Demokratyczno-Republikańskiego, premier Francji (XI 1934 - VI 1935) oraz szef kolaboracyjnego rządu Vichy (XII 1940 - II 1941).

${ }^{36}$ Pierre Laval (1883-1945), francuski polityk, premier Francji (I 1931 - II 1932; I 1935 I 1936). W czasie II wojny światowej podją się kolaboracji z Niemcami i dwukrotnie stał na czele rządu Vichy (VII-XII 1940; IV 1942 - VIII 1944). Za współpracę z okupantem osądzony i 15 X 1945 r. rozstrzelany.

${ }^{37}$ Marcel Déat (1894-1955), francuski publicysta, polityk socjalistyczny, minister lotnictwa (1936), z czasem germanofil. W latach 1940-1945 kolaborował z rządem niemieckim, minister pracy i sprawiedliwości społecznej Vichy (1944-1945); zaocznie skazany na śmierć ukrywał się po zakończeniu II wojny światowej we Włoszech.

${ }^{38}$ Georges Bonnet (1889-1973), francuski polityk, lider Partii Radykalno-Socjalistycznej, 
de Monzie ${ }^{39}$ and many others. Many distinguished soldiers were also strongly opposed to action. The masses were utterly pacifist. Neutral observers who talked to soldiers on their way to the frontiers reported upon their ill temper. Nothing was ever more popular amongst the French masses than the Munich settlement.

A shock for the Quai d'Orsay.

All this came as a great shock to those who regarded France's Eastern commitments as vital to the life of the country, and directly [after] the crisis was over they asserted themselves. Although the Czechoslovak business had swept them off their feet they were quite determined nothing like it should happened again. They earnestly and sincerely believed that it was their mission to use every available means to prevent a similar occurrence. The trouble simply was that, like most intellectuals, they were not in very close touch with the masses. They quite failed to understand that the people were unprepared for eastern alliances, and would not go an inch beyond the mere defence of their own frontiers. They did not realize the great gulf between their foreign policy and public opinion. They quite honestly persuaded themselves that a handful of politicians had basely betrayed the traditional policy of France. Their indignation was understandable, even though their reading of the public temper was lamentably wrong.

Pressure on the British Parliament by French Foreign Office.

The Quai d'Orsay mobilised all its resources. The utmost influence was brought to bear upon the press, politicians and, above all, the British Government. Even many whose better judgment warned them of the dangers, learned to repeat the tragic catch phrases which were to become so powerful, that they trapped those who had invented them and helped to lead France to the very edge of, and finally into the abyss.

The belief in bluff.

Two schools of thought were to prevail, those who believed that the Polish alliance could effectively be carried out ${ }^{40}$, and those who thought that to say so would bluff Hitler out of aggression. M[ister] Daladier was amongst the latter, but absurdly enough everyone knew it. Anyone with moderately good contacts in Paris could hear what the French Prime Minister had said about

wielokrotny minister, m.in. spraw zagranicznych (1938-1939). Podczas II wojny światowej członek Rady Narodowej Vichy, w 1944 r. uciekł z Francji do Szwajcarii, w której pozostał do 1950 r. Zaocznie sądzony za kolaborację, ale nie skazany.

39 Anatole de Monzie (1876-1947), francuski polityk, członek konserwatywnej La Parti social français oraz L’Union socialiste républicaine, długoletni parlamentarzysta oraz wielokrotny minister.

${ }^{40}$ Mowa o sojuszu polsko-francuskim podpisanym 19 II 1921 r. w Paryżu. 
it on this or that occasion. It was well known in Berlin. Many colleagues shared his view. It was an easy way out of many problems: it saved the bother of disputing with those who really believed in the policy in a positive sense, and it was the simplest way of arguing with the isolationists.

The critics silent.

Little by little an atmosphere was created in which to criticise or questioned the Polish alliance was akin to treachery, and so opposition was gradually silenced, until at the last not a voice was raised in protest. M[ister] Laval sat in his office cynically shrugging his shoulders. M[ister] Flandin, whose foolish Munich telegram to Hitler hurt him politically, retired to the country. All held their tongues. The channel of communication between London and Paris was narrowed and, unhappily the British Government was unaware that all the apparent unanimity was nothing more than a deceptive facade behind which was seething discontent and utter defeatism.

\section{Sanguine Activists.}

The activists were incredibly sanguine. One of our observers who visited Paris in June $1939^{41}$ discussed the situation at a private luncheon with two distinguished generals and two former ministers ${ }^{42}$. He was so disturbed by the extreme optimism which prevailed that on his return to London he wrote a note to one of them criticising certain points in the theories propounded. He asked that the note be circulated to the others. In reply one of the generals wrote:

"Thank you for your communication, in which you have been good enough to enclose a letter from M[iste]r... To tell the truth, I failed to follow its conclusion. I quite see that he has little confidence in the states of Eastern Europe. For all that, the 60 Polish and 18 Romanian divisions are not negligible, and we should do well to have them with us $^{43}$. I do not speak of Turkey or Greece, all that follows... We are not at liberty to choose our own hour, and whether it be Danzig or Tiensin, we must now courageously accept the challenge of force.

As you said so strongly the other day, one must not permit to Germany or to Italy anything which concerns a modification of the status quo in Europe, otherwise France and Britain will remain alone in the face of totalitarian bloc, having disillusioned their small allies... There remain the Russian question. I do not believe, all the same, that Russia could enter into the

\footnotetext{
${ }^{41}$ Nazwisko wysłannika nie do ustalenia.

${ }^{42}$ Nazwiska ministrów i generałów nie do ustalenia.

${ }^{43}$ Według ostatniego polskiego planu mobilizacyjnego armia polska mogła maksymalnie wystawić 46 dywizji piechoty, przy czym we wrześniu 1939 r., również w wyniku odwołania 29 sierpnia zarządzeń mobilizacyjnych, Polsce udało się wystawić pełnych 39 dywizji piechoty i 2 improwizowane oraz 11 brygad kawalerii.
} 
group of totalitarian nations, for two reasons: first, the soviet ideology is absolutely opposed to the ideology of Germany and Italy... Secondly, America and France in order to face this Asiatic danger ${ }^{44}$. Thus, even if at the beginning of a conflict, Russia is not with us, she will be obliged during the general conflagration to range herself on our side.

M[iste]r... talks of the better base from which we can strike. Does he think that the base will be better if we lose our Eastern European allies, by counselling them to make concessions? The whole question resolves itself into this. Ought we to temporise vis a vis Germany and Italy? For my part I think not. For after Danzig it will be the status of the Mediterranean and the colonies. Perhaps the British and French would understand better a more direct reason for war in the defence of our empires, but we must explain to them the present situation and they will understand it. As I see it, the French people are already committed".

The General's optimism.

The general was convinced that Poland would fight for many months, and could eventually be supported by Russia ${ }^{45}$. He was also certain that Rumania would join in, and the Balkans would gradually range themselves with the allies. He, like many members of the French general staff, was convinced that French defences were impregnable. It was this appreciation of the situation, and this advice which, through a very narrow channel, was reaching official London.

Warnings from behind the scenes of state.

Behind the scenes, however, disquieting reports from our observers had been accumulating. One of the first contained this significant passage:

"...During a couple of days stay in the French capital we had a number of conversations. We had one and a half hours with M[ister] Leger ${ }^{46}$, permanent head of the French Foreign Office... We found that M[ister] Leger, when cross examined, related the whole of French Foreign Policy to the question of what contribution of a military character Great-Britain might be prepared to make. This seems to be the end of everybody's observations, and we left Paris with the feeling that if France is threatened with a serious international situation, she will make her policy conditional upon our ability to land at any given time a very substantial expeditionary force, and that if we cannot promise this, France may capitulate, throwing the blame upon us... From all our conversations we gathered that there is a growing

\footnotetext{
${ }^{44}$ Brakuje dalszej części zdania.

${ }^{45}$ Te nadzieje okazały się płonne, a ZSRS - po podpisaniu paktu Ribbentrop-Mołotow 23 VIII 1939 r. - zaatakował Polskę 17 września.

${ }^{46}$ Zob. przypis 9 .
} 
body of opinion in Government, as well as in other circles, which intends to make the question of the British army a very serious issue... The general tendency in France, which is a very grave one, is to say that if Great-Britain will build up a substantial army in addition to her air and sea power, then the French are prepared to go on fulfilling the role a first class power, but if Great-Britain is not prepared to do this and propose to confine her military contribution to the navy and air force, then they are not going to take the risks of remaining a first class power and are even prepared to take a second place in Europe.

...Although the internal French situation has improved, we believe there is cause for acute anxiety, having regard to the extraordinary unanimity with which everyone related French foreign policy, even in respect to her own vital interest, to the size and strength of the British army. This seems to be the excuse for a general policy of retreat. We could not say that this excuse is eagerly sought for, or much desired - on the contrary, most Frenchmen would feel deeply humiliated if France became a second class power, but are not prepared to make a greater sacrifice than Great-Britain, even for the maintenance of their position in Europe.

Many British observers profoundly disagree with our views:

[...] in our opinion we believe that the life and death of France as a first class power depends upon our decision in respect of the army. It is impossible to over-estimate the place which this question takes in the thoughts of most French politicians today".

\section{General Brécard's Warning.}

Last month we referred to General Brécard's Memorandum which we published in February 1939, on the same subject ${ }^{47}$. It was hardly desirable at that moment to publish the precise extract which we had in mind, which read as follows:

"...The political agreements which unite two nations whose interests are identical, have only a relative value if they are not complemented in the military sphere, and if in the event of hostilities one of the two nations risks being crushed before the other has had time to come her help...We therefore must ask our British friends to examine closely their Metropolitan army...We are not asking too much if we expect their land force to give us know perfectly well in France that Great-Britain will only with great difficulty agree to any profound modification of her military system of voluntary recruiting. Each nation has its traditions, and we have too much respect for our British friends

${ }^{47}$ Charles Théodore Brécard (1867-1952), francuski generał, w 1914 r. po wybuchu Wielkiej Wojny szef francuskiej misji wojskowej przy armii belgijskiej, w latach 1927-1932 główny inspektor kawalerii, członek Najwyższej Rady Wojennej oraz wojskowy gubernator Strasbourga (1929-1932). Od 1932 r. na emeryturze. W 1940 r. stanął u boku marszałka Pétaina. 
not to understand that they feel little disposed to undertake such a task, but the circumstances in which we may suddenly find ourselves in the near future are exceptional, and for such exceptional circumstances, exceptional measures must be adopted... We are firmly convinced that our friends will understand how tragic the actual situation is and how profound is the need for a transformation. We have enough confidence in their common sense and good judgement to feel that the necessary adjustments will be made".

A word from the Enemy camp.

As if to endorse this, the German General Beck ${ }^{48}$ said in his Staff essay, published in our issue of May 193949: “... From what quarter then can France expect aid? How can she withstand the block of 125 million Germans and Italians? How can she resist blackmail? Those are questions which from now on must stand in the fore front and background of all French and British military alliance for all contingencies; rearmament in all directions, not only in the military sphere; rapid creation of a French air force; creation of a great foreign legation from all the elements and refugees living in France and others foreigners; increase in the colonial army, for only by means of colonial troops and «foreigners» can the strength of the French army be increased. For Britain: immediate introduction of compulsory military service; immediate training of ten classes (men between the ages of 20 and 30); similarly in the dominions ${ }^{50}$; support of British and French rearmament by America in the form of credits and supplies of material (in particular aeroplanes and aero engines). This represents an immediate programme on the execution of which all the political, economic and intellectual resources of the Western Powers must be concentrated".

"If this is not done, and it is very probable that it will not be done, or only very incompletely, then the Western Powers will not be able, or hardly able, to withstand the Axis Powers..."

\section{Daladier fails to confide in Britain.}

The tragedy is that evidently M[ister] Daladier and General Gamelin ${ }^{51}$ did not make the same requests to the British Government that highly placed politicians were to make to unofficial visitors behind the scenes. The critical weeks thus saw one page after another added to a chapter of misunderstandings.

\footnotetext{
${ }^{48}$ Ludwig Beck (1880-1944), niemiecki generał, twórca Wehrmachtu, przeciwnik polityki Hitlera dążącego do wybuchu II wojny światowej, należał do organizatorów nieudanego zamachu na życie kanclerza w Wilczym Szańcu na Mazurach.

${ }^{49}$ Nie udało nam się ustalić tej pozycji.

${ }^{50}$ W tym czasie samorządne dominia tworzyły: Kanada, Australia, Nowa Zelandia oraz Związek Południowej Afryki.

${ }^{51}$ Maurice Gustave Gamelin (1872-1958), francuski generał, uczestnik walk podczas I wojny światowej, współodpowiedzialny za porażkę Francji w 1940 r.
} 
M[ister] Daladier was certainly aware of the exact number of divisions which we could send on the outbreak of war and the number which would be available in the $9^{\text {th }}$ month of hostilities of that fact Mr. Churchill ${ }^{52}$ has reminded us.

A private word from a Member of the French War Cabinet.

There is no doubt, however, that privately this question of land forces was much discussed up to the last. For instance, a member of the inner French War Cabinet ${ }^{53}$ wrote to us on $12^{\text {th }}$ April in the following terms:

"... I want to take the opportunity in this letter of bringing to your attention the great interest there is in Britain's development and acceleration of her Continental military effort to reinforce the French divisions on guard behind the Maginot Line ${ }^{54}$. This, for France, is a very important question upon which I must be permitted to insist.

...First of all, there is the moral aspect, for the spirit of my country is much worked upon by German propaganda at this moment...

There is, in addition, for France a considerable economic interest; The extent of our mobilisation from the point of view of output alone, is a problem which becomes more acute every day. France lacks men to work in factories for developing her export and for augmenting her interior production.

Consequently, she has to buy a good deal from the foreigner without sufficient exports to pay for them. The drain upon gold and currency cannot in the end be without affect upon the financial situation of the country.

Finally, the French General Staff is preoccupied by the difference between the mobilised strength of France and England and that of Germany, who in any event has a favourable strategic position because her troops move along interior lines. At the present moment we have only two divisions against three. I do not know whether the importance and urgency of this problem is sufficiently understood in England. May I be permitted to press it objectively and cordially".

The question of Daladier's evident silence.

The great question is, why did not M[ister] Daladier and General Gamelin inform the British Government officially and categorically both during the summer of 1939 and subsequently, that the arm forces of France were insufficient for her commitments. They should have stated plainly that unless

52 Winston Churchill (1874-1965), brytyjski polityk, pierwszy lord admiralicji 1939-1940, dwukrotny premier Wielkiej Brytanii w latach 1940-1945, 1951-1955.

${ }^{53}$ Nazwisko nie do ustalenia.

${ }^{54}$ Linia Maginota - francuski system umocnień powstały po I wojny światowej przede wszystkim na granicy z Niemcami i Luksemburgiem. Fortyfikacje wznoszono na skutek defensywnej doktryny wojennej Francji, która zakładała, błędnie, prowadzenie w kolejnym konflikcie zbrojnym wojny pozycyjnej. 
Great Britain could guarantee a certain number of divisions within a specified period it would be impossible for France to carry out her obligations. Although all this was hinted at to private visitors and in unofficial correspondence, M[ister] Churchill has told us that M[ister] Daladier was fully informed as to the number of British divisions which would be available and, with that knowledge, he at no time called a halt.

Further, behind the scenes of States was the opinion of the masses in July 1939, we sent an observer to tour provincial France, for our anxieties were rapidly increasing and we wanted them either resolved or confirmed. Amongst several reports he sent us, one was especially significant. He wrote:

“... In the provincial towns life continues undisturbed. There is no war talk and no apparent nervousness. Few Frenchmen that you talk to enter into a discussion of the international situation. If you bring the subject up yourself they will talk without enthusiasm, employing many clichés - «Hitler must be stopped». "France and Britain must be strong». "We must do everything in our power to avoid another war». One and all in answer to my question, "Do you think we shall be fighting this year?» said: "No. Things will arrange themselves. There will be an Entente»... The impression I had almost universally was that they were desperately refusing to believe in the possibility of the another war... I think - and of course this is nothing more than my own instinct- that they will welcome anything which will postpone or seem to remove the danger of a European war. My conclusions are that the French will fight well enough, if without great enthusiasm, if they are forced to, but the majority will welcome any measure or appeasement or postponement which will dissolve, for however short a time, the clouds of war". On $1^{\text {st }}$ August 1939, another report reached us from a special observer whom we had sent to France. His words were disquieting:

The danger of a separate peace.

"My conclusions are:

That the French are not anything like so keen on having a slap at Hitler as we think...

When the bleak facts reveal themselves, they are unlikely to honour their obligations to an Eastern Ally.

If intense pressure from London shakes the French into honouring such an obligation they will find that a successful offensive is impossible and they will either throw the blame on us for not providing a sufficient force, or, alternatively, demoralisation will gradually set in and they will conclude a separate peace.

This is more or less the old story that I have reported over and over again. I do want to make it very clear that if a British visitor went to Paris, I doubt if he will find a single Frenchman who would in plain terms confirm 
the contents of this report. You can' $\mathrm{t}^{55}$ get a plain, straight forward statement like that out of any Frenchman - at any rate only a very few ${ }^{56}$. But if you draw the picture of what will probably happen, go over all the military ground, argue it all out at considerable length, it will be found in the final issue that most Frenchman either get so annoyed that they won't speak at all, or alternatively, that they shrug their shoulders and say it is a matter for the Military Staff.

A letter from Berlin.

Reports continued to reach us on the same line. On August $31^{\text {st }}$ the French Cabinet met at the height of the crisis, and M[ister] Daladier was on the point of capitulation when there arrived from Berlin a letter from M[ister] Coulondre ${ }^{57}$, the French Ambassador in Germany. It was sent over the head of M[ister] Bonnet directly to the Prime Minister. It contained an assurance that if France stood firm Germany would not march and that in the Ambassador's view Hitler's policy was one of pure bluff. This strengthened the hand of those who, although against war, had held that very view. It also strengthened the position of the activists. After a few more restless meetings and a great deal more indecision, France - with extreme reluctance - went to the length of declaring war upon the Third Reich ${ }^{58}$. Her military action, however, was confined to a minor demonstration in the Saar, and beyond that it was not to go, until the advance into Belgium, which was to end in a retreat towards the extremities of France ${ }^{59}$.

Political unrest from the first.

No sooner war was declared than political intrigue started afresh; the isolationists were determined to bring it to the earliest possible conclusion at the conference table. Then the Communists got to work on Germany's behalf in every nook and corner of France. In order to counteract all this, the Activists persuaded M[ister] Daladier to impose the strictest measures. The press was heavily censored, individuals who expressed the slightest doubt as to the outcome of war were locked up. Many foreign visitors to Paris were regarded with suspicion. Every resource of propaganda was mobilised in order to persuade the French people that Germany was in extremis and that the war would be won quite comfortably.

${ }^{55}$ Dopisek odręczny.

${ }^{56}$ Brakuje dalszej części zdania.

${ }_{57}$ Robert Coulondre (1885-1959), francuski dyplomata, ambasador Francji w Berlinie w latach 1938-1939.

${ }^{58}$ Francja wypowiedziała wojnę III Rzeszy 3 IX 1939 r.

${ }^{59}$ Ta sytuacja znana jest pod takimi nazwami, jak drôle de guerre, phoney war czy Sitzkrieg, a decyzja w Abbeville z 12 IX 1939 r. francusko-angielska Najwyższa Rada Wojenna postanowiła nie angażować się wówczas w działania wojenne. 
France in difficulties.

The facts, however, were very different. Germany's passive policy in the West was, as we know, deliberately calculated to undermine the morale of France. Grumbling in the army grew to alarming proportions. The authorities could not arrest the defeatists fast enough. The Germans concentrated Nazi propaganda upon the upper classes, and spread communist propaganda amongst the masses. The fifth column grew to enormous proportions. Officers could be heard in the cafés saying that soon they would be marching back to Paris. The rank and file, receiving grumbling letters from their wives at home, became even more difficult to console. It was estimated by observers that $90 \%$ of the women of France were ready for peace at almost any price.

\section{German lies.}

The Germans started the story that France had gone to war under British pressure, whereas in fact it was to honour a French alliance that Great-Britain had really marched. Much was made of the smallness of the British Army and at this criticism many Frenchmen were only too anxious to grasp. The total inadequacy of the French Air Force many Frenchmen were inclined to forget. Anti-British sentiment spread far and wide, assuming most alarming proportions.

The activists, however, were still to remain hopelessly optimistic. A distinguished French statesman who was shortly to join the French Cabinet, writing to a member of this group on December $25^{\text {th }}, 1939$, said:

The activists remain hopeful.

“... For the moment I do not think that the French General Staff is preparing an offensive against Germany. The Siegfried Line ${ }^{60}$, like the Maginot Line, constitutes a redoubtable fortification against aggression, making the offensive very expensive for little gain... I believe that... have the conviction that Hitler will take the offensive in April, passing by Holland and Belgium or Switzerland, or even by all three countries ${ }^{61}$. This would be to our profit... There is a reason to believe that this German offensive after its initial success will be arrested and will meet a final check which will gravely damage Hitler's prestige and that of the Nazi régime...

For the rest, the effects of the blockade and the insufficient financial resources of Germany will lead to an exhaustion more rapid than that of the allies".

${ }^{60}$ Linia Zygfryda - niemiecki system umocnień na granicy z Francją i Luksemburgiem.

${ }^{61}$ Ostatecznie Niemcy zaatakowały Holandię i Belgię 10 V 1940 r. Państwa te po kilku dniach skapitulowały, odpowiednio 14 i 28 maja. Plany ataku na Szwajcarię nie zostały zrealizowane. 
Some reasons for Daladier's downfall.

If it had not been for the Finnish business M[ister] Laval might have come to power last December. He was in favour of separate peace with Germany. The Finnish war ${ }^{62}$ gave the people something to think about, and generally fingered up the propaganda machine. Then came M[ister] Daladier's downfall. This was engineered for the most part by the Isolationists, and not by those who wanted the more efficient prosecution of the war. That was the pretext, but it was a fraud. Powerful influences had been at work. It was thought necessary to give the Reynaud ${ }^{63}$ regime a run for its money and then, when it was proved that the situation was no better, to sweep the activists out, and put the negotiators in.

Plots against M[ister]Reynaud's policy.

$\mathrm{M}$ [ister] Reynaud is an experienced hand in politics and he well knew what was happening. He expressed the opinion that unless something was done to break stalemate his Government would not last ten days. He agreed to redressing Norwegian neutrality ${ }^{64}$ and the declaration that France would not make a separate peace. On his return to France, however, he found that certain aspects of the allied plans were strongly objected to, and that some of his colleagues were furious at the "No separate peace" declaration. Full details of what followed these disputes cannot yet be published. It is enough to say that M[ister] Daladier and his friends imposed conditions upon M[ister] Reynaud which made the effective prosecution of the war virtually impossible; and also made it clear that the declaration was of little importance.

Reynaud's Government badly shaken.

At the time of Germany's western thrust, M[ister] Reynaud's Government was again in danger from the isolationists, for the collapse of Norway had dealt a shattering blow to the activists. In our considered view, it was only a question of a very short time before France would in any case have been at the conference table. The military calamities which followed so swiftly one upon another and led to the dismissal of General Gamelin and fifteen of his colleagues left M[ister] Reynaud in his saddle, but badly shaken. The country was becoming ever more restive. The summoning of Marshal Pétain ${ }^{65}$

\footnotetext{
${ }^{62}$ Wojna sowiecko-fińska prowadzona w latach 1939-1940. Obnażyła wszystkie słabe strony ZSRS, który pomimo formalnej wygranej nie zdołał podporządkować sobie Finlandii.

${ }^{63}$ Paul Reynaud (1878-1966), premier Republiki Francuskiej od 21 III 1940 r., a następnie minister spraw zagranicznych od 5 do 16 czerwca tegoż roku.

${ }^{64}$ Hitler zaatakował Danię i Norwegię 9 IV 1940 r.

${ }^{65}$ Henri Philippe Pétain (1856-1951), marszałek Francji, szef rządu Vichy, prowadził politykę kolaboracji z Niemcami.
} 
to the Vice-Premiership and the appointment of General Waygand ${ }^{66}$ help to steady the pulse, but only temporary. When the enemy started breaking through on the Somme and the Aisne, France's capitulation was certain $^{67}$.

A distinguished Visitor to London.

It is at this point that we need to assess events very soberly. Just before the last battle started, a distinguished though unofficial French visitor arrived in London. He paid a number of visits with the object of pointing out the extreme gravity of the French position. He explained that the chances of holding the Germans on the Somme and the Aisne was extremely small; that the loss of Paris was almost certain, and that it was difficult to see any end to the retreat of the French army. He explained that there was reason to fear that Germans would set up a Communist Government in Paris which would undoubtedly be widely supported throughout the country and might have far-reaching political repercussions throughout the world. He expressed the opinion that the policy of withdrawing from France was impracticable because of the difficulty of persuading French sailors to blockade their own wives and children for any long period; in any event a French Government would certainly be formed, Communist or otherwise, which would make terms with the enemy. He was, therefore, of the opinion that it would be far better that terms should be negotiated by some reliable and properly constituted Government than by revolutionaries.

Weygand's difficulties.

His view was proved to be only too well founded. It is very difficult to know why Marshal Pétain did not ask for a meeting of the Supreme War Council ${ }^{68}$ and lay before the Allied Governments a fresh appreciation of the situation before approaching the enemy.

This was evidently not done. It must be remembered, however, that the breakdown of France was complete. General Weygand was tying to command his armies from a small provincial hotel with a single telephone. Millions of refugees were blocking the roads. They were homeless, without food and without prospects. The major of industrial France was already in German hands, and nearly all the territory which has been included in the terms of armistice was already occupied.

\footnotetext{
${ }^{66}$ Maxime Weygand (1867-1965), francuski generał, współodpowiedzialny za porażkę Francji w wojnie z Niemcami, pełnił m.in. obowiązki ministra obrony w rządzie Vichy.

${ }^{67}$ Mowa o przebiegu frontu w północnej Francji na początku czerwca 1940 r. wzdłuż linii rzek Sommy, Oise i Aisne.

${ }^{68}$ Najwyższa Rada Wojenna.
} 
The people's attitude to Pétain.

In our considered opinion, Pétain's action represented the desires of an overwhelming majority of the French people. That statement may be criticised, but nevertheless it is the conclusion to which we have been forced, and is based upon a mass of reports stretching over a period of years and bringing us down to the last period. It is quite possible, however, that the very act of capitulation and the terrible nature of the armistice terms may produce reaction. We may have to differentiate between the opinion of France during the retreat, and that which grows in the days of armistice. But it would be quite wrong to suggest that Marshal Pétain objected in principle. They may come to criticise it later.

Pétain's \& Weygand's persistent warnings.

History will show that both Pétain and Weygand had for months warned the French Cabinet of the dangers which lay ahead, and there is evidence to show how they tried to avert them. General Weygand's memoranda during the first months of the war were not those of a defeatist, for in the military sense he at that time belonged to the activist school, and was indeed at some difference with Paris on that very subject. Our principal observer was shown one of his confidential reports which proved this beyond all doubt.

Pétain's capitulation.

So far as Marshal Pétain is concerned he has for a very long time been a bitter critic of the political regime in his country. History will undoubtedly condemn his action in not pursuing the Reynaud conversations with Great Britain on the subject of peace, but will also take extenuating circumstances into account. Even though on the balance the Marshal Pétain is found guilty of a grievous mistake in not awaiting a release from Britain and reserving the fleet, his great services to France over a long and distinguished career, and especially his patriotic warnings of recent months, all rank him as having once been a staunch Frenchman. The General disregard of his warnings and the tragic state of his country no doubt embittered him at the last and, pressed on many sides by demoralised politicians, anxious advisers, and harassed civilians, he cut through all formalities and reservations and, even as Mr. Churchill was already on his way for further conversations, he cast the die. In the last hours the Marshal became very old, and, alas, a defeated man.

The future of Anglo-French relations.

We must know now forget the very representative character of the Marshal's Cabinet. Later it may or may not come to be hated by French people - that depends on the reactions, the most enduring of which will only develop gradually. Whatever opinion we may hold about the Marshal's action, our 
attitude to the whole business may well determine the nature of AngloFrench relations for a generation or more. We cannot disregard the fact that France has broken a solemn pledge and has acknowledged Germany's right to use French territory for operations against us. At the same time we shall neither harm our own cause nor that of Europe if we are generous enough to take into the fullest account the appalling dilemma which faced the French Government at the last, and the terrible calamities which the French people passed. Those who sincerely treasure good relations between the British and the French peoples will take care not to judge the aged Marshal and his colleagues too harshly, for in so doing we shall gain nothing, and we may well alienate a large section of French opinion.

Attitude towards the French Exiles.

It ought not to be difficult to reconcile a deep understanding of Marshal Pétain difficulties with admiration for those Frenchmen who, despite all reverses, are anxious and determined to continue fighting for France on Britain's side, with all the resources at their command. They, least of all, would wish the British public to form a harsh opinion of the France from which they are at present exiled, or of the distinguished soldiers, sailors, and airmen, many of whom for various reasons have had to take another opinion.

Political prospects of France.

Although it is too early yet to estimate what the internal political repercussions will be, we can examine certain guiding facts from the recent past. On the extreme left there was an active and widespread Communist movement and the right the P.S.F. ${ }^{69}$ which grew from the old Croix de $\mathrm{Feu}^{70}$. Of this party Colonel de la Rocque ${ }^{71}$ is leader and it has a wide following throughout the country. Although the Colonel declaims any royalist leanings, his brother $^{72}$ is secretary of the Comte de Paris and there are many royalists in the party's rank.

The fate of the guilty political groups.

Between the two extremes are the innumerable groups and parties, nearly all of which have their full share of responsibility for France's difficulties.

${ }^{69}$ Parti social français (PSF) - partia konserwatywna o zabarwieniu nacjonalistycznym powstała w 1936 r. po rozwiązaniu Croix-de-Feu.

70 Francuska skrajnie prawicowa i nacjonalistyczna organizacja działająca w latach 1927-1936, jej działania kontynuowała PSF.

${ }^{71}$ François de La Rocque (1885-1946), polityk związany z francuską prawica, założyciel Croix-de-Feu i PSF, po początkowym zaakceptowaniu polityki kolaboracji z Niemcami zmienił swoje stanowisko i we wrześniu 1942 r. podją współpracę z francuskim ruchem oporu.

${ }^{72}$ Pierre de La Rocque (1880-1954). 
Most of them will now pay heavy price, and we shall very likely see a general "sauve qui peut" 73 , with politicians scuttling into one extreme party or the other. Observers have always been greatly divided in their opinions as to which way France would move in such a crisis - would it be towards the Right or the Left? The balance of opinion has been that at first moment there would be a grave danger of communism, but if the worst moment could be passed, then the tendency would be towards the right. The instinct of most ex-officers (and there will be thousands of them) will be towards some form strong right-wing movement and since there is no single outstanding Communist figure who is not well known to have been in German pay, the masses may find it hard to resist the claims of the Right. Moreover anti-Semitism has been rife of late and during recent weeks has reached great proportions ${ }^{74}$. Hatred of the freemasons has also been growing and both the tendencies are certainly from the Right. Further, the people remember that it was the leftists who opposed armaments and who voted against the Maginot-Line credits. It was they who quarrelled with Italy and Spain, while putting their faith in a Russia which never fired a shot except against the Finns. Moreover, many in France remember that it was the influence of the extreme Left-wingers which led to the arrest and imprisonment without charge or trial of men like the Duke Pozzo di Borgo ${ }^{75}$ and General Duseigneur ${ }^{76}$, who had both served with the utmost distinction during the first great war. They were advocates of rearmament, of a strong foreign policy, and of cleaning up French political life. Both were released without explanation or apology on pressure from powerful American and English friends. This sort may yet be paid for; the French have long political memories, and even though they do not like dukes, they are proud of generals and love freedom.

The record of the Right Wing.

On the other hand, the Right Wing in France has always been hopelessly ineffective and divided. There will be bitter heart-searching in France in the weeks to come and there will be some little time lag before most Frenchmen make up their minds where they stand politically. Tremendous issues will depend upon the course of events. One thing is certain; the old order

${ }^{73}$ Wyrażenie: „ratuj się, kto może” (fr).

74 „Ustawa żydowska” obowiązywała we Francji od 3 X 1940 r. Od tego czasu można mówić o systematycznej wywózce zagranicznych (bez obywatelstwa) Żydów do obozów zagłady. Eskalacja tego procederu miała miejsce od czerwca 1941 r. Szacuje się, że z terenu Francji deportowano do niemieckich obozów koncentracyjnych 76 tys. Żydów.

75 Joseph Pozzo di Borgo (1890-1966), francuski pilot z czasów I wojny światowej, działacz skrajnej prawicy.

${ }^{76}$ Edward du Seigneur (1882-1940), francuski pilot, brał udział w walkach podczas I wojny światowej, następnie służąc w wojsku, awansował do stopnia generała, później związany z prawica. 
of parliamentary intrigue, corruption and place-seeking will certainly swept away. For a long time resentment has been growing, now it will reach feverheat. Whatever the immediate consequences, almost any outburst will be for the good, for France had lost her will-power, and so long as she regains the character to take SOME action, however dangerous, that will be the first step towards the re-birth of what is fundamentally a great race and will remain so. 